JPH: Jurnal Pembaharuan Hukum

Volume 8, Number 3, December 2021

\title{
CONCEPT OF APPRAISAL INSTITUTIONS IN ASSESSING THE VALUATION OF INTANGIBLE ASSETS ON SMALL MEDIUM ENTERPRISES INTELLECTUAL PROPERTY AS OBJECT OF CREDIT GUARANTEE TO IMPROVE COMMUNITY'S CREATIVE ECONOMY
}

\author{
Anis Mashdurohatun \\ Sultan Agung Islamic University \\ anism@unissula.ac.id \\ Gunarto \\ Sultan Agung Islamic University \\ gunarto@unissula.ac.id \\ Oktavianto Setyo Nugroho \\ Sultan Agung Islamic University \\ oktaviantosn@gmail.com
}

\begin{abstract}
This study aims to analyze the factors that affect the effectiveness of Intangible Assets of Intellectual Property of Small and Medium Enterprises as objects of credit guarantees, and the concept of appraisal institutions in assessing the valuation of intangible assets of intellectual property of Small and Medium Enterprises as objects of credit guarantees in order to improve the creative economy of the community. The method used in this research is empirical juridical. The data used are primary data and secondary data. Data collection techniques data collection through library research and field studies (through questionnaires, focus group discussions, and interviews). The results of the study found that the five factors that affect the effectiveness of Intangible Assets intellectual property of Small and Medium Enterprises as objects of credit guarantees are legal factors, law enforcement, infrastructure, society and culture. The legal factor that affects is there is no special legal product for public appraisers of IPR Intangible assets. In the practice, IPR intangible assets have not been accepted by all banks as objects of basic guarantees but only as objects of additional guarantees. It is caused by no trust from the bank toward the value of IPR as basic guarantees, there have been no appraisal institutions, and there is not intellectual property rights market yet, that makes IPR is not commonly used by banks and SMES as IP owners. The concept of appraisal institutions in assessing the valuation of intangible assets of intellectual property of small and medium businesses as objects of credit guarantees, in order to improve the creative economy of the community, is necessary to form an appraisal agency through the products of laws and regulations. These regulations, among others, regulate the intangible assets of IPR, the purposes and objectives of the IPR assessment, the requirements to become an IPR appraiser, the function and authority of IPR assessment, the valuation method used, and so on.
\end{abstract}

Keywords: Credit; Intangible Assets; IP Assessment; SMES.

Jurnal Pembaharuan Hukum Volume 8 No.3 September-December 2021
CONCEPT OF APPRAISAL INSTITUTIONS IN ASSESSING THE VALUATION OF INTANGIBLE ASSETS ON SMALL MEDIUM ENTERPRISES INTELLECTUAL PROPERTY AS OBJECT OF CREDIT GUARANTEE TO IMPROVE COMMUNITY'S CREATIVE ECONOMY Anis Mashdurohatun, Gunarto, Oktavianto Setyo Nugroho 


\section{A. INTRODUCTION}

Micro, Small and Medium Enterprises (MSMEs) have a strategic role in national economic development, because apart from playing a role in economic growth and employment ${ }^{1}$, they also play a role in the distribution of development outcomes ${ }^{2}$. MSMEs need to prepare themselves to be able to compete both in terms of comparative advantage and competitive advantage. $^{3}$ Increasing economic development to increase the competitiveness of MSMEs depends on the effective management of knowledge and technology.

The fact that the creative economy is now a globalized concept, with many countries looking to the UK for guidance on growing the sector. The UK's long-running focus on creativity, and the assumed role of the so-called 'creative economy' in ensuring national, regional and local competitiveness is at this point well examined. In the last five to ten years there have been very significant though unevenly distributed improvements in information and communications technology (ICTs), leading to growth in digital creative production, distribution, and consumption. ${ }^{4}$

In international forums, the IPR has been recommended to be used as an object of debt guarantees. Regarding IPR as a guarantee of debt and has even been discussed in the United Nations Commission on International Trade Law (Uncitral) and has produced "Uncitral Legislative Guide on Security Transactions on Security Rights in Intelectual Property. ${ }^{5}$ Countries such as America, Australia, Malaysia have implemented Intellectual Property as a Credit Guarantee.

The development of SMEs to date still has various problems, especially regarding business capital, and the protection of intellectual property rights. Intellectual property rights (IPR) are intangible assets that have economic value and provide benefits for SMEs. ${ }^{6}$ This is a condition for the IPR intigible assets of SMEs to become fiduciary guarantees. Since approximately 21 years ago, Act No. 42 of 1999 concerning Fiduciary Guarantees and products of IPR legislation, which stipulates that IPRs can be used as fiduciary guarantees, has not yet been effective.

Based on this background description, it is interesting to study in more depth the Factors that influence effectiveness intangible Assets of

1 Zuliyati, Zamrud Mirah Delima, 2017, Intellectual Capital dan Kinerja UKM, BIMA, Pascasarjana (S2) STIE Dharmaputra Semarang, page. 281.

2 Anis Mashdurohatun \& M. Ali Mansyur, Product Capabilities Dynamic on Industrial Design Carved Wood in Small and Medium Enterprises (SMES) Jepara Furniture in Promoting the Protection of Intellectual Property Rights, International Journal of Applied Engineering Research, Vol.12, No.19, 2017, page. 8217-8226.

3 Mukole Kongolo, Job creation versus job shedding and the role of SMEs in economic development, African Journal of Business Management, Vol.4 No.11, 4 September, 2010

4 Ealasaid Munro, Building Soft Skills In The Creative Economy: Creative Intermediaries, Business Support And The Soft Skills Gap, Poetics, Vol.64, October 2017, pages 14-25

5 Widiyanti Dwi Maynarni, Intellectual Property Rights as a Debt Guarantee, Legal Information Window in Trade, Cemetrian Trade of the Republic of Indonesia, April 2015, page 25

6 Muh Ali Masnun, Menggagas Perlindungan Hukum Bagi Usaha Mikro Kecil Dan Menengah Atas Hak Desain Industri Di Indonesia, Dialogia Iuridica: Jurnal Hukum Bisnis dan Investasi, Vol.11 No.2, April 2020, page.16-24 
Intellectual Property of Small and Medium Enterprises as objects of credit guarantees, and the concept of appraisal institutions in assessing the valuation of intangible assets of intellectual property of Small and Medium Enterprises as objects of credit guarantees in order to improve the creative economy of the community.

\section{B. RESEARCH METHODS}

This type of research is qualitative research, ${ }^{7}$ is research that is used to examine human and social problems. Where the researcher will report the results of the research based on the view of the data and analysis of the data obtained in the field, then described in the research report in detail. Research that aims to understand the phenomena experienced by research subjects. It is more appropriate and suitable to be used for researching matters relating to research on the behavior, attitudes, motivations, perceptions and actions of the subject. The research design has three formats. The three formats include descriptive research, verification and grounded research format. ${ }^{8}$ Law is not conceptualized as an autonomous normative phenomenon, but a social institution that is actually related to other social variables. The approach used in this research is social legal research, ${ }^{9}$ with a non-positivistic paradigm, which conceptualizes law as a norm and at the same time as reality. The data used are primary data and secondary data ${ }^{10}$. Primary data collection techniques are carried out by observation, focus group discussions and interviews. The data will be analyzed using an interactive model which includes 3 (three) activities, namely data reduction, data presentation and drawing conclusions or verification.

\section{RESULTS AND DISCUSSION}

\section{Factors Affecting the Effectiveness of Small and Medium Enterprises Intellectual Property Intangible Assets as Credit Guarantee Objects}

The consequence of Indonesia's participation as a member of the World Trade Organization (WTO) is to take important steps including aligning the set of laws and regulations in the field of Intellectual Property (IP) with the provisions of the Trade-Related Aspects of Intellectual Property Rights (TRIPs) Agreement. The development of the global community, IPR has become one of the access to obtain banking credit internationally.

Intellectual Property Rights (such as copyrights, patents, and trademarks) have become a source of bank financing. Even the inclusion

7 Lexy J. Moeleong, Metode Penelitian Kualitatif, Remaja Rosdakarya, Bandung, 2014, page.4

8 Sugiyono, Memahami Penelitian Kualitatif, Dilengkapi Contoh Proposal dan Laporan Penelitian, Alfabeta, Bandung, 2015, page 25

9 Brian Z Tamahana, Realistic Socio-Legal Theory Pragmatism and a Social Theory of Law, Oxford University Press, New York, 1997, page 1

10 Mukti Fajar ND \& Yulianto Achmad, Dualisme Penelitian Hukum Normatif dan Empiris, Yogyakarya, 2010, page 156 
of Intellectual Property as a guarantor, is to ensure security for creditors by taking over all company assets, as well as adding a line of financial resources for debt recovery. SMEs owners/holders of IPR who need additional capital in order to develop their business can access bank credit. $^{11}$

The factors that influence the effectiveness of Intangible Assets of Intellectual Property of Small and Medium Enterprises as objects of credit guarantees, based on the theory of legal effectiveness according to Soerjono Soekanto ${ }^{12}$ above, states that the effectiveness or failure of a law is determined by 5 factors, namely the legal factor (laws), enforcement factors law (the parties that form or apply the law), factors of facilities or facilities that support law enforcement, community factors (the environment in which the law applies or is applied), and cultural factors (as the result of works, creativity and taste based on human initiative in life association). Bronislaw Malinowski analyzes the effectiveness of law in society which can be divided into two, namely modern society and primitive society. Modern society is a society whose economy is based on a broad market, specialization in industry and the use of advanced technology. In modern society the law made and determined by the competent authority is enforced by the police, courts and so on, while primitive society is a society that has a simple economic system and in primitive society does not recognize the tools of power. Meanwhile, according to Lawrence M. Friedman, legal substance, legal structure and legal culture.

The legal factor, in practice, is that few banks are willing to accept IP as a guarantee object in the Fiduciary Guarantee System. Currently, one of the ways that can be expected from the creative economy sector to increase the added value of this sector is intellectual property. ${ }^{13}$ The need for alternative funding is a contemporary development in the field of intellectual property, especially for creative industries that are full of intangible assets. With the scheme of using IPR as a fiduciary guarantee to obtain bank financing, it is expected to improve the welfare of creative economy actors. Fiduciary is the transfer of ownership rights to an object on the basis of trust with the stipulation that the object whose ownership rights are transferred remains in the control of the owner of the object. Fiduciary Security according to Act No. 42 of 1999 concerning Fiduciary Guarantees (which is called UUJF) is a guarantee right on movable objects, both tangible and intangible and immovable objects, especially buildings that cannot be encumbered with mortgage rights as referred to in Act No. 4 of 1996 concerning Mortgage Rights that remain in the control of the Fiduciary Giver, as collateral for the repayment of certain debts, which gives priority to the Fiduciary Recipient to other creditors.

11 Anis Mashdurohatun, Gunarto, Comparison of Trademark Laws as Fiduciary Guarantee Objects, Advances in Social Science, Education and Humanities Research, Vol.192, Atlantis Press, 2018, page. 188.

12 Ibid.

13 Yunita Hikmia, Hak Merek Sebagai Jaminan Tambahan Pada Perbankan, Jurist-Diction, Vol. 2 No. 4, July 2019, page 1497. 
The object in question is everything that can be owned or transferred, both tangible and intangible, registered or unregistered, movable or immovable which cannot be encumbered with mortgages or mortgages.

In the material nature of IPR, which is one of the intellectual rights, there are two rights, apart from economic rights which can provide benefits in the form of royalties, there are also moral rights which are always attached to the owner. Economic rights that are owned by someone for their creativity can be transferred or transferred to other people, so that other people as recipients of the transfer of rights also get economic benefits.

In civil law, interpretation according to analogy is often used due to its nature which generally only regulates and does not force. The interpretation of trademark rights as objects of fiduciary guarantees, because trademark rights include intangible movable objects. Therefore, based on an analogous interpretation, this is possible considering that the right to a mark as part of the law of objects, namely movable objects that are not tangible (rights) are regulated in Article 499 of the Civil Code, Paragraph 1 Point 2.4 of the Fiduciary Guarantee Law, can be transferred or transferred because agreement, as regulated in Article 41 Paragraph (1) of Act No. 20 of 2016 concerning Marks and Geographical Indications, that a mark can be transferred due to inheritance, will, waqf, grant, agreement and, other reasons justified by the provisions of laws and regulations invitation. ${ }^{14}$

From an economic perspective, a mark has economic value. From the perspective of the law of objects, IPR is an intangible right or object that can be transferred or transferred due to an agreement and from a guarantee law perspective. In relation to the brand as a fiduciary guarantee in order to encourage economic development, the law not only provides justice, certainty and benefits from the economic aspect, but also from the social aspect which becomes the brand's good image/good will from the public as consumers. Law has an important role in economic activities related to the provision of capital through bank credit facilities. ${ }^{15}$

Developments regarding the need for financing based on IPR, the government through several laws in the field of intellectual property has provided a legal protection. Among other things, through Act No. 28 of 2014 concerning Copyright, in which Article 16 paragraph 3 stipulates that copyright can be used as an object of fiduciary guarantee. Then in Article 108 paragraph 1 of Act No. 13 of 2016 concerning Patents which states that patent rights can be used as objects of fiduciary guarantees. The fiduciary guarantee is the transfer of ownership rights to an object

14 Sri Mulyani, Konstruksi Konsep Hak Atas Merek Dalam Sistem Hukum Jaminan Fidusia Sebagai Upaya Mendukung Pembangunan Ekonomi, MMH, Ed. 43 No. 2, 2014, page. 213223

15 Jacinta Winarto, Hubungan Antara Citra Merek Dengan Ekuitas Merek, Jurnal Manajemen, Vol.10, No.2 May 2011, Page 110 
on the basis of trust provided that the object whose ownership rights are transferred remains in the control of the owner of the object. The existence of these regulations also does not necessarily make IPR steps as an object of fiduciary guarantees bankable or creditworthy.

The assessment carried out by the Appraiser aims to: $a$. transaction; b. private sector and public sector financial reporting; $c$. debt guarantee; d. state revenue; and e. Other Assessment purposes according to Indonesian Valuation Standards. The provisions of the Regulation of the Minister of Finance of the Republic of Indonesia Number 228 / PMK.01/2019 concerning the Second Amendment to the Ministerial Regulation! Finance Number 101/PMK.01/2014 Regarding Public Appraisers Ministerial Regulation! Finance of the Republic of Indonesia Number 228 /PMK.01/2019 Regarding the Second Amendment to the Ministerial Regulation! Finance Number 101/PMK.01/2014 concerning Public Appraisers, contains provisions that business appraisals cover the field of intellectual property rights and intangible assets as set out in Article 5 Paragraph (1) \& (4)e. Article 5 (1) The field of Appraisal services includes: a. Simple Property Valuation; b. Property Valuation; c. Business Appraisal; and D. Personal Property Valuation. (4) The field of Business Appraisal services as referred to in paragraph (1) letter c includes the Assessment of: a. business entity; b. participation; $c$. securities including their derivatives; $d$. the rights and obligations of the company; e. intellectual property rights and intangible assets; $f$. economic loss caused by a certain activity or event to support various corporate actions or material transactions; g. fairness opinion; and $\mathrm{h}$. financial instruments.

Collateral is one way to minimize the risk of failure or delay in repaying debt, where in Article 11 of the Banking Law it is stated that Bank Indonesia stipulates provisions, one of which is the provision of guarantees, then in accordance with Act No. 21 of 2011 concerning the Financial Services Authority with the task of regulating and banking supervision was transferred from Bank Indonesia to the Financial Services Authority. The provision of collateral in this loan is regulated in Article 45 of POJK No. 40 of 2019, does not yet regulate intellectual property.

Currently, one of the ways that can be expected from the creative economy sector to increase the added value of this sector is intellectual property. The need for alternative funding is a contemporary development in the field of intellectual property, especially for creative industries that are full of intangible assets. ${ }^{16}$ With the scheme of using IPR as a fiduciary guarantee to obtain bank financing, it is hoped that it can improve the welfare of creative economy actors. ${ }^{17}$ However, in practice, there are still few banks that are willing to accept KI as a guarantee object in the Fiduciary Guarantee System.

16 Op.Cit, Page 1497.

17 Raymond Kusuma \& Ariawan Gunadi, Analisis Hak Atas Merek Sebagai Agunan Dalam Pemberian Kredit Bank, Jurnal Hukum Adigama, Vol.3 No.2, December 2020, page.287-310 
The period of IPR protection is limited, there is no clear concept related to due diligence, IPR asset valuation, and IPR appraisal agencies in Indonesia, and there is no juridical support either in the form of regulations related to IPR assets as objects of bank credit guarantees or revisions to Bank Indonesia Regulations ( PBI) concerning Asset Quality Assessment of Commercial Banks related to credit collateral is one of the main factors why banks have not been able to accept HKI as objects of bank credit guarantees. To realize this renewal concept, firm and detailed juridical support is needed regarding IPR assets as objects of bank credit guarantees, thorough socialization, and the existence of an IPR appraisal agency in Indonesia. ${ }^{18}$

The legal structure factor, there is no understanding and agreement between the Financial Services Authority, Bank Indonesia and the Ministry of Human Rights Law as well as public appraisal institutions that assess the valuation of IPR values that will be used as collateral for financing. In addition, there is also no institution that can assess or appraisal of an IPR. Also, there are still issues regarding how the binding mechanism for IPR in terms of IPR certificates will be used as collateral in obtaining financing. In the future, this obstacle will be the focus not only of the government such as the OJK or the Ministry of Law and Human Rights, but also expected collaboration and synergy from academics, business actors, and other stakeholders in the intellectual property sector. It is hoped that stakeholders will make the intellectual property legal system adaptable to the provisions regarding the guarantee system in financial institutions.

Legal culture factors, legal culture/culture is an element of social attitudes and values. ${ }^{19}$ The cultural component, which consists of values and attitudes that influence the operation of the law by Lawrence $M$. Friedman, is referred to as legal culture that functions as a bridge that connects legal regulations with the legal behavior of all citizens.

Legal culture includes the understanding given to law by the community, areas of legal inter-subsystem legal system, basic understanding, paired values. The culture and civilization of mankind begins and culminates with philosophical values which are developed and enforced as an ideological system. ${ }^{20}$ This means that the value of

18 Kurnianingrum, T. P., Hak Kekayaan Intelektual Sebagai Jaminan Kredit Perbankan (Intellectual Property As Banking Credit Guarantee), Negara Hukum: Membangun Hukum untuk Keadilan dan Kesejahteraan, Vol.8 No.1, 2017, page.31-54

19 Anis Mashdurohatun, Adhi Budi Susilo, Bambang Tri Bawono Copyright Protection Towards The Society 5.0, Journal of Southwest Jiaotong University, Vol.56 No.2 Apr. 2021, page.398. see too Lawrence M. Friedman, The Legal System: A Sosial Science Perspective, Rusel Sage Foundation, New York, 1975, page.17.

20 Ideology is the whole system of thinking, values, and basic attitudes of a particular social or cultural group. The meaning of ideology according to the Oxford dictionary is (1) a set of ideas that an economic or political system is based on; (2) a set of beliefs, especially one held by a particular group, that influences the way people behave. Meanwhile, according to Martin Hewitt, ideology is the system of ideas and imagery thaough which people come to see the word and define their needs and aspiration, and 'a system of ideas, beliefs and values that individuals and societies aspire toward. See Martin Hewitt, Welfare, Ideology 
philosophy as the highest reach of thought to find the essence of truth (ultimate truth), is therefore made a philosophy of life. A view of life (weltanschauung), at the same time exuding the soul of the nation (volksgeist), being the nation's self and national dignity. ${ }^{21}$

There are three things that distinguish the culture of Indonesian society from the IPR legal system. The culture of Indonesian society is communal, spiritual and inclusive, while in the IPR legal system, it is individualistic, materialistic and exclusive. This is very influential in the implementation of intellectual property rights as a guaranteed credit ${ }^{22}$ where banks and small and medium enterprises have not yet taken advantage of the IPR.

Intangible Assets Intellectual property of Small and Medium Enterprises as objects of credit guarantees is not commonly used by banks and SMEs as owners of IPR. This is due to several factors including; juridically, laws and regulations are not yet equipped, especially regarding public appraisal agencies specifically assessing the valuation of intellectual property assets of Small and Medium Enterprises, so that in practice not all banks can accept Intellectual Property (copyrights, trademarks, patents etc.) as objects of credit guarantees, structurally Legally, there is no understanding and agreement between the Financial Services Authority, Bank Indonesia and the Ministry of Human Rights Law, and according to the legal culture, banks and small and medium enterprises have not taken advantage of it.

\section{Concept of Appraisal Institutions in Assessing the Valuation of Intagible Assets of Intellectual Property of Small and Medium Enterprises as Objects of Credit Guarantees to Improve Community Creative Economy}

Indonesia is a State of Law. Since Pancasila was established as the basis of the Indonesian state, philosophically, Pancasila has been a filter in harmonizing legal development in response to legal globalization. ${ }^{23}$ Legal development has a more comprehensive and more

and Need, Developing Perspectives on the Welfare State, Martin Hewitt, 1992, Welfare, Ideology and Need, Developing Perspectives on the Welfare State, Maryland, Harvester Wheatsheaf, Page. 1.

21 See MNS, Lab. UM's Pancasila, the Pancasila Philosophy System as a National Ideology Embodied in the 1945 Constitution of the Proclamation (Enforcing the National Identity of the Nation And Character Building, Paper presented at the Productive Community Education Forum in the Framework of Strengthening the Ethics of National and State Life, for the people of Blitar Regency and City, 23 February 2011, page. 2.

22 Anis Mashdurohatun, Communal vs. Exclusive Establishment of Islamic Law Values in Developing Intellectual Property Rights Law, Inaugural Speech of Professor of the Faculty of Law, Unissula Semarang, 15 October 2020.

23 Globalization of the world today and its development in the future refers to 4 (four) main points: First, globalization is a global thing which is characterized by increasingly intensive business and trade activities between countries. Second, globalization triggers the emergence of a science and technology-based economy. Third, globalization encourages competition between nations which requires every country to have strong competitiveness, including maintaining the sovereignty of the nation and state and territorial integrity. Fourth, the nation's competitiveness can be built properly if it is supported by a fair and 
basic meaning, than the term legal development or renewal. Legal development is not only focused on the rules or legal substance but also on the legal structure or institution and the legal culture of the community. Legal development is directed to support the realization of a sustainable economy in accordance with Act No. 17 of 2007 concerning the National Long-Term Development Plan of 2005-2025. ${ }^{24}$

Valuation of intellectual property rights becomes very important as a guarantee in obtaining bank financing. Therefore, it is currently necessary to have an independent party tasked with determining the valuation of a person's intellectual property rights before being made the object of financing guarantees at the bank. This will further support the government's program in realizing the creative economy of the community, especially for Small and Medium Enterprises.

Creative economy is a concept in the new era of economics that prioritizes creativity. The concept of the creative economy prioritizes human resources who have knowledge and unusual creative ideas to be used as the main key to production activities and advance the economy. The goals of the creative economy are to increase the contribution of products, especially to gross domestic product, to help increase the value of exports, to add new jobs due to the increasing demand for labor, and to increase the number of competitive companies, especially in the creative economy, as well as to strengthen the branding of local products in the country. ${ }^{25}$

For the formation of Indonesian legal regulations, Pancasila is the source of all sources of law, as stipulated in Article 2 of Act No. 12 of 2011 concerning the Establishment of Legislation which states that Pancasila is the source of all sources of state law. The placement of Pancasila as the source of all sources of state law is in accordance with the fourth paragraph of the Preamble to the 1945 Constitution, namely Belief in One Supreme God, just and civilized humanity, Indonesian unity, democracy led by wisdom in deliberation/representation, and social justice for all Indonesian people. . Then put Pancasila as the basis and ideology of the state as well as the philosophical basis of the state so that any material content of laws and regulations must not conflict with the values contained in Pancasila.

The concept of appraisal institutions in assessing the valuation of intangible assets of intellectual property of small and medium enterprises as objects of credit guarantees in order to improve the creative economy of the community needs to be formed by an IPR assessment agency

free market. See Frasminggi Kamasa, The Age Of Deception of Riba in Economic Globalization, Global Politics and Indonesia, Gema Insani, Jakarta, 2012, page. 13. See too Wayan Lasmawan, Era Disrupsi Dan Implikasinya Bagi Reposisi Makna Dan Praktek Pendidikan (Kaji Petik Dalam Perspektif Elektik Sosial Analisis), Jurnal Media Komunikasi Pendidikan Pancasila dan Kewarganegaraan, Vol.1 No.1 April 2019, page 57.

24 Adi Sulistiyono, Economic Law, Teaching Materials at PDIH FH UNS, Surakarta, 2020

25 Anis Mashdurohatun, Ariy Khaerudin, and Teguh Prasetyo Intellectual Property Protection of Indigenous Peoples in Indonesia: Quo Vadis?, Sociological Jurisprudence Journal, Vol.3 Issue. $1 ; 2020$ 
through the products of laws and regulations. These regulations, among others, regulate the Appraisal Institution of Intellectual Property, the aims and objectives of the IPR assessment, the requirements to become an IPR appraiser, the function and authority of the IPR appraisal, the definition of Valuation, the valuation method used, and so on.

In various countries such as America, Australia and Malaysia, the definition of valuation is identical to market value. Valuation in America is a value should be separated into two main classifications, market value or non-market value. The most widely quoted definition of market value is the most probable price, at a given date, in cash, or in cash equivalent terms, or in other appropriately disclosed terms, at which a particular property right must be sold after a reasonable exposure in a competitive marketplace under all conditions necessary for a fair sale, with the buyer and seller each acting with care, knowledge and self-interest and on the assumption that neither is under pressure.

According to the Australian Property Institute, the accepted definition of Australian market value is: The estimate of the amount a property must exchange at the date of valuation between a willing buyer and seller directly after the appropriate marketing length of the transaction where the parties have each acted with knowledge, prudence carefully, and without coercion.

Meanwhile According to the Malaysian Valuation Standards (MVS), the definition of valuation is as follows: A written opinion regarding the capital or rental value on any basis with respect to an interest in the property, with or without any assumptions or qualifications. The concept of value is always theoretical while price is usually factual. There may be a certain ask price and a selling price, about which there should be no disagreements or differences of opinion. However, value is basically an opinion without a perfectly competitive market, there is no certainty that the value sought is really true or cannot be challenged.

According to Earl Naumann" in his book entitled "Creating Customer Value: The Road to Sustainable Competitive Advantage," customer value or ratings provided by customers consist of several components, namely Product Quality, Service Quality, Price and Image. The four components determine consumer ratings. A high rating score determines the company's perception of value. When this theory is applied to calculate the economic value of a copyrighted work, then the quality of the product, service, price and image owned by a work, will qualify to be accepted as an object of guarantee by the bank, because copyright has fulfilled the elements that can be marketed and secure for loan repayment.

The appraisal institutions approach method in assessing the valuation of intellectual property assets of small and medium enterprises as objects of credit guarantees in order to improve the community's creative economy, there are 3 approach methods, including the Cost

26 Earl Naumann, Creating Customer Value: The Path To Sustainable Competitive Advantage, Framsida, Thomson Executive Press, 1995, page.279 
Approach Method, Market Approach Method and Income Approach Method $^{27}$.

The Cost Approach method will completely make a choice, namely whether to use historical or current costs, the basic principle underlying it is substitution. This principle states that the value of an object or piece of intellectual property is not greater than the cost of acquiring that asset elsewhere, whether the cost of acquiring the asset is measured by buying it today or replacing it with a substitute asset of the same strength and power utility.

There are different variations of the cost approach method, and each uses a slightly different definition of cost. For example, the difference between reproduction cost and replacement cost may seem like a matter of semantics, but in reality, the two terms can be very different things. The cost of reproduction determines what is required to build an exact replica of the intellectual property. Replacement costs determine what is required to create or purchase a piece of intellectual property with the same functionality or utility.

An alternative approach to cost methodologies, historical and prospective, is valuing the value of an intellectual property or set of assets by measuring the expenditure required to replace the asset being valued. Whether historical or future costs are being determined, three general areas of cost should be examined:

a. hard costs, such as materials and asset acquisition

b. software costs, including engineering time, design time, and overhead

c. market costs, including advertising or other costs to establish a market for intellectual property

The cost method establishes the value of an IP asset by calculating the cost of a similar (or exact) IP asset. The cost method is particularly useful when the IP asset can be easily reproduced and when the economic benefits of the asset cannot be measured accurately. This method does not take wasted costs into account, nor does it take into account the unique or new characteristics of the asset.

Market Approach Method The market approach to the valuation of intangible assets is used as is the case for the valuation of tangible assets. In other words, intellectual property or intangible assets are valued by comparing them to recent sales, transfers, and transactions involving similar assets in the same market (the greater the similarity, of course, the more suitable the transactions are for comparison purposes). As the name suggests, the market approach to the valuation of any asset, tangible or intangible, is most applicable when a truly active market exists and actual transactions can be found.

Even where an active market can provide market comparisons, similar transactions used must also be adjusted to reflect differences

27 Kelvin King, A Case Study in the Valuation of a Data base, Data base Marketing \& Management, Vol.14 No.2, 2017, page. 819-830 
between transactions, and differences in the intellectual property or intangible assets being valued.

The market approach to valuation has traditionally been used with tangible assets where an active market has existed for decades, in areas such as real estate, equipment, and raw materials. However, most intangible assets, at least to date, have not been bought and sold frequently enough to be able to assign value based solely on direct market-based comparisons; therefore, analysis and adjustments are almost always required. In addition, intangible asset transactions are often shrouded in multiple layers of secrecy.

Therefore, it is usually difficult to obtain sufficient detail on any similar or comparable transaction to ensure that all of the value elements that make up the comparison for use in the market approach have been properly considered. On the other hand, since the market approach uses actual transaction data as much as possible, and value is derived from the sale, transfer, licensing, or other activity of similar assets, this approach is increasingly preferred if the necessary data can be found.

Using a market approach relies on finding one or more comparable transactions and then extrapolating those comparable transactions to the value of the intellectual property under review.

The market method is based on comparison with the actual prices paid for the transfer of rights to similar IP assets under comparable circumstances. This method has the advantage of being simple and based on market information, so it is often used to establish approximate values for use in determining royalty, tax, and input rates for the revenue method.

Revenue Approach Method This income approach is based on determining the future stream of income that can, or will, be generated from the intellectual property or intangible assets being valued. The revenue approach is a widely used intellectual property valuation methodology; however, this can be tricky, and one must decide how to measure the "revenue" attributable to the asset.

A quick example illustrates this: An inexperienced analyst might see that a branded product earns a 30 percent higher profit margin than its unbranded counterparts, and the expert is tempted to attribute the entire 30 percent to a trademark or brand. In fact, only part of that 30 percent is attributable to actual intellectual property, as the balance of increased profits may be due to cheaper materials or more efficient manufacturing of branded products. With this caveat in mind, the three basic parameters of the revenue approach are:
a. Future income stream
b. Duration of income stream
c. The risk or discount rate associated with the revenue stream

The nitty-gritty comes in identifying alternative measures of economic income that can be used in this kind of analysis. This can include net income, gross income, gross profit, operating income, income 
before tax, operating cash flow, EBITDA (earnings before interest, taxes, depreciation and amortization), net cash flow, expected additional income, etc.

The most common mistake in applying this approach is the lack of expert distinction between the revenue generated by the total business enterprise, or the value of the business enterprise, and the value of the income generated by the intellectual property in that business. When valuing intellectual property, to use the revenue approach, it is critical to be able to separate the revenue stream generated by intellectual property (and therefore its value), from the overall business value, and then apply the appropriate discount rate and life span.

In short, when using the income approach, the calculated value of intellectual property or intangible assets represents the present value or value of future economic benefits/income that the owner will (or should) obtain. This requires a projection of future income, an estimate of the duration of the revenue stream and/or useful life, and an estimate of the risks associated with generating the revenue stream, also known as the discount rate. Although at first glance it may seem less precise than the cost approach, due to the inclusion of several input assumptions, often the information needed to make these assumptions can be developed accurately and verified based on market conditions and market data.

The main benefit of the earnings approach is that it gives expert analysts the ability to perform sensitivity analyzes by adjusting various parameters, such as the revenue rate or discount rate. This allows the expert to better understand the performance of the various factors driving the value, and allows estimates of upper and lower limits to the range of values.

The revenue method is the most commonly used method for IP valuation. It values IP assets based on the amount of economic revenue it is expected to generate, adjusted for today's value. This method is easiest to use for IP assets with positive cash flows, for assets whose cash flows can be estimated with a certain degree of reliability for future periods, and where a risk proxy can be used to derive a discount rate. ${ }^{28}$

Regardless of the method used, the valuation process requires gathering a wealth of information about an IP asset, as well as an indepth understanding of the specific economy, industry and business that directly affect its value. This information can be obtained by conducting an event-based IP audit ${ }^{29}$, as well as background research.

28 Jody C. Bishop, The Challenge of Valuing Intellectual Property Assets, Northwestern Journal of Technology and Intellectual Property, Vol.1, Issue.1, Spring 2003, page 59-65.

29 Tulika Rastogi. IP Audit: Way to a Healthy Organization, Journal of Intellectual Property Rights. Vol.15, July 2010, Page 302-309. in general intellectual property audits by purpose includes 3 (three) types, namely (1) General purpose IP audit general), (2) Event driven IP audit and (3) Limited purpose IP audit. Slamet Yuswanto, Business Development Analysis Based On Intellectual Property, Jurnal Lingkar Widyaiswara, Issue 4 No. 4, October December 2017 
The value of IP assets is influenced by the strength of the underlying legal rights and their commercial utility, which is determined by their functional and economic characteristics.

Therefore, the valuation of these assets should use multidisciplinary input. Prior to conducting an IP assessment, it should consider whether they are competent to identify and assess the relevant characteristics of the subject asset, and/or whether another expert opinion is required. As legal, technical and market factors can materially affect the value of IPR, it is important for users of valuation reports to be informed of the extent to which these factors have been assessed, or whether they are covered by assumptions. If the intangible asset is international in its use, or potential use, and its rights are subject to legal protection, expert legal advice may be required. The assessor must disclose whether the subject's IP ownership has been determined through a legal assessment or whether this is a specific assumption of the report. ${ }^{30}$

The valuer should consider the nature and attributes of the subject IP as well as the nature and characteristics of the market for the asset to determine the most appropriate valuation approach. The heterogeneous nature of many intangible assets means that there is often a greater need to consider the use of different methods and approaches than for other asset classes. This is especially true for IP, which by definition is unique. There will be instances where information gaps or other difficulties would jeopardize the use of all assessment approaches. In this situation, the appraiser must use more than one method to support the main assumptions and opinions of the appraisal.

In the case of IP, the use of sensitivity analysis to perform crosschecks and fairness checks on asset valuations can be of great benefit to both appraisers and users of valuation reports. Integrate IP characteristics into each assessment approach.

Assessment of the functional utility of patents and other IPtechnology categories may require a high level of technical expertise. Disclosure should be made as to whether there are any limitations to the scope of IP-tek's functional assessment, including such matters as the breadth and validity of claims and freedom to operate.

In terms of legal structure, Directorate General of Intellectual Property grand vision is to achieve The Best IP Office in The World, based on the spirit of clean and serving bureaucratic reform. Through the preparation of the Directorate General of Intellectual Property Strategic Plan for the 2020-2024 period. To realize Directorate General of Intellectual Property to be a public servant in the field of Intellectual Property which has a vital role in the National Creative Ecosystem. Creative industries and business actors have shifted in interpreting IP. Currently, IPR is not only seen conventionally as a form of moral

30 Tim Heberden FRICS (Deloitte), 2020, Valuation of intellectual property rights, RICS professional standards and guidance, global Valuation of intellectual property rights 2nd edition, London, Page.11. 
recognition and as an economic incentive for a creation. IP optimization paradigm as working capital. The context of optimizing IP as working capital means that IP is a guarantee instrument used to guarantee debt.

To determine the economic value of an intellectual property, it is necessary to have a professional appraiser who is competent to calculate the valuation of intellectual property. According to Sabartua, to answer the need for IPR appraisers, it can be done by adding to the competence of existing appraisers or establishing a new professional certification agency with the specificity of intellectual property appraisers.

In a legal structure, there should be an understanding and agreement between the Financial Services Authority, Bank Indonesia and the Ministry of Human Rights Law, so that it creates high bank confidence in the intangible assets of IP and small and medium businesses can make more use of Intangible assets in order to improve the creative economy of the community, both nationally and internationally global.

In terms of legal culture, in developing IPR law through a legal culture, realizing individualistic_exclusivism_materialistic IPR which becomes a religiously inclusive communalistic in which the recognition and protection of IPR individually but still does not ignore communal interests so as to create moral and social responsibility in the use of IPR in local and national communities, and vice versa Communal Intellectual Property can also provide individual and communal benefits. On the other hand, value or moral education as a global issue in several countries (Indonesia, Malaysia, India, and China) shows differences and similarities. The differences are caused by differences in national ideology. However, these countries place emphasis on moral value education on ethical-moral values; especially in terms of values that are human, universal, and global.

Thus, legal education ${ }^{31}$ related to culture in the form of moral ethics at the level of affection needs to be started early, because it is very useful in shaping the mental attitude of people who respect each other, help each other, work together to form unity and preserve the sustainability of life together.

\section{CONCLUSION}

Factors that affect the effectiveness of Intangible Assets of Intellectual Property of Small and Medium Enterprises as objects of credit guarantees, are not commonly used by banks and SMEs as IPR owners. This is due to several factors including; Juridically, laws and regulations are not yet equipped, especially regarding public appraisal agencies specifically

31 Satjipto Rahardjo explained that legal education must introduce a new perspective that requires (holistic) so that legal education is not to produce competitive and competitive human beings, but graduates who are able to distribute divine values such as justice, truth, and honesty as the basis for the existence of law to become glue (social unity), so that legal science is required to be progressive. See Satjipto Rahardjo, Legal Education as Human Education, Genta Publishing, Yogyakarta, 2009, page. 14 
assessing the valuation of intellectual property assets of Small and Medium Enterprises, so that in practice not all banks can accept Intellectual Property (copyrights, trademarks, patents etc.) as objects of credit guarantees, structurally Legally, there is no understanding and agreement between the Financial Services Authority, Bank Indonesia and the Ministry of Human Rights Law, and according to the legal culture, banks and small and medium enterprises have not taken advantage of it. The concept of an appraisal agency in assessing intangible assets of intellectual property of Small and Medium Enterprises as an object of credit guarantees in order to improve the creative economy of the community, it is necessary to form an IPR assessment agency through the products of laws and regulations. These regulations, among others, regulate the intangible assets of IPR, the purposes and objectives of the IPR assessment, the requirements to become an IPR appraiser, the function and authority of IPR assessment, the valuation method used, and so on.

\section{BIBLIOGRAPHY}

\section{Books:}

Adi Sulistiyono, 2020, Economic Law, Teaching Materials at PDIH FH UNS, Surakarta;

Brian Z Tamahana, 1997, Realistic Socio-Legal Theory Pragmatism and a Social Theory of Law, Oxford University Press, New York

Earl Naumann, 1995, Creating Customer Value: The Path To Sustainable Competitive Advantage, Framsida, Thomson Executive Press;

Frasminggi Kamasa, 2012, The Age Of Deception of Riba in Economic Globalization, Global Politics and Indonesia, Gema Insani, Jakarta;

Jimly Asshiddiqie, 2019, Ideology, Pancasila, and the Constitution, MKRI, Jakarta;

Lawrence M. Friedman, 1975, The Legal System: A Sosial Science Perspective, Rusel Sage Foundation, New York;

Lexy J. Moeleong, 2014, Metode Penelitian Kualitatif, Remaja Rosdakarya, Bandung;

Martin Hewitt, 1992, Welfare, Ideology and Need, Developing Perspectives on the Welfare State, Maryland, Harvester Wheatsheaf;

Mukti Fajar ND \& Yulianto Achmad, 2010, Dualisme Penelitian Hukum Normatif dan Empiris, Yogyakarya;

Satjipto Rahardjo, 2009, Legal Education as Human Education, Genta Publishing, Yogyakarta;

Sugiyono, 2015, Memahami Penelitian Kualitatif, Dilengkapi Contoh Proposal dan Laporan Penelitian, Alfabeta, Bandung; 
Tim Heberden FRICS (Deloitte), 2020, Valuation of intellectual property rights, RICS professional standards and guidance, global Valuation of intellectual property rights 2nd edition, London;

Zuliyati, Zamrud Mirah Delima, 2017, Intellectual Capital dan Kinerja UKM, BIMA, Pascasarjana (S2) STIE Dharmaputra Semarang;

\section{Journals:}

Anis Mashdurohatun \& M. Ali Mansyur, Product Capabilities Dynamic on Industrial Design Carved Wood in Small and Medium Enterprises (SMES) Jepara Furniture in Promoting the Protection of Intellectual Property Rights, International Journal of Applied Engineering Research, Vol.12, No.19, 2017;

Anis Mashdurohatun, Adhi Budi Susilo, Bambang Tri Bawono Copyright Protection Towards The Society 5.0, Journal of Southwest Jiaotong University / Vol.56 No.2 Apr, 2021;

Anis Mashdurohatun, Ariy Khaerudin, and Teguh Prasetyo Intellectual Property Protection of Indigenous Peoples in Indonesia: Quo Vadis?, Sociological Jurisprudence Journal, Vol.3; Issue.1; 2020;

Anis Mashdurohatun, Gunarto, Comparison of Trademark Laws as Fiduciary Guarantee Objects, Advances in Social Science, Education and Humanities Research, Vol.192, Atlantis Press, 2018;

Chandra Yusuf \& Derta Rahmanto, Strengthening The Ipr Law: Additional Provisions Setting The Use Of Valuation To Achieve Consistency Assessment Of Intangible Assets, Journal of Lex Librum, Vol.V, No.1, December 2018;

Ealasaid Munro, Building Soft Skills In The Creative Economy: Creative Intermediaries, Business Support And The Soft Skills Gap, Poetics, Vol.64, October 2017;

I Gede Agus Kurniawan, Valuasi Merek sebagai Jaminan Kredit Perbankan: Relevansi dalam Pembentukan Lembaga Penilai Kekayaan Intelektual, Jurnal Magister Hukum Udayana, Vol. 9 No. 4 December 2020;

Jacinta Winarto, Hubungan Antara Citra Merek Dengan Ekuitas Merek, Jurnal Manajemen, Vol.10, No.2, May 2011;

Jody C. Bishop, The Challenge of Valuing Intellectual Property Assets, Northwestern Journal of Technology and Intellectual Property, Vol.1, Issue 1, Spring 2003;

Kelvin King, A Case Study in the Valuation of a Data base, Data base Marketing \& Management, Vol 14 No.2, 2017;

Kurnianingrum, T. P., Hak Kekayaan Intelektual Sebagai Jaminan Kredit Perbankan (Intellectual Property As Banking Credit Guarantee), Negara Hukum: Membangun Hukum untuk Keadilan dan Kesejahteraan, Vol.8 No.1, 2017; 
Muh Ali Masnun, Menggagas Perlindungan Hukum Bagi Usaha Mikro Kecil Dan Menengah Atas Hak Desain Industri Di Indonesia, Dialogia Iuridica: Jurnal Hukum Bisnis dan Investasi, Vol.11 No.2, April 2020;

Mukole Kongolo, Job creation versus job shedding and the role of SMEs in economic development, African Journal of Business Management Vol.4 No.11, 4 September, 2010;

Raymond Kusuma \& Ariawan Gunadi, Analisis Hak Atas Merek Sebagai Agunan Dalam Pemberian Kredit Bank, Jurnal Hukum Adigama, Vol.3 No.2, December 2020;

Slamet Yuswanto, Business Development Analysis Based On Intellectual Property, Jurnal Lingkar Widyaiswara, Issue.4 No.4, October December 2017;

Sri Mulyani, Konstruksi Konsep Hak Atas Merek Dalam Sistem Hukum Jaminan Fidusia Sebagai Upaya Mendukung Pembangunan Ekonomi, MMH, Ed.43 No. 2, 2014;

Tulika Rastogi, IP Audit: Way to a Healthy Organization, Journal of Intellectual Property Rights, Vol.15, July 2010;

Wayan Lasmawan, Era Disrupsi Dan Implikasinya Bagi Reposisi Makna Dan Praktek Pendidikan (Kaji Petik Dalam Perspektif Elektik Sosial Analisis), Jurnal Media Komunikasi Pendidikan Pancasila dan Kewarganegaraan, Vol. 1, No.1 April 2019,

Widiyanti Dwi Maynarni, Intellectual Property Rights as a Debt Guarantee, Legal Information Window in Trade, Cemetrian Trade of the Republic of Indonesia, April 2015;

Yunita Hikmia, Hak Merek Sebagai Jaminan Tambahan Pada Perbankan, JuristDiction, Vol.2 No.4, July 2019;

\section{Others:}

Anis Mashdurohatun, Communal vs. Exclusive Establishment of Islamic Law Values in Developing Intellectual Property Rights Law, Inaugural Speech of Professor of the Faculty of Law, Unissula Semarang, 15 October 2020. 